\title{
Migration won't make Chinese deserts bloom
}

\section{Diverting water is not enough. Fragile land such as Xinjiang needs care, not exploitation.}

Sir - In the Commentary "Agriculture of the future" (Nature 428, 215-217; 2004),

T. C. Tso argues that the Chinese government should use the country's three most important resources - people, land and water - to their best effect. We agree with this general principle. But we have three reservations regarding turning the Xinjiang region into the "California of China".

First, the author gives the impression that Xinjiang is largely undeveloped and has "abundant resources". Yet the area is home to 11 people per $\mathrm{km}^{2}$, far exceeding the international population-density standard for arid areas of 7 people per $\mathrm{km}^{2}$. Some $95 \%$ of the population live in oases totalling less than $60,000 \mathrm{~km}^{2}$. The population density in oases, at 292 inhabitants per $\mathrm{km}^{2}$, reaches that of many coastal cities. Far from being "undeveloped", the area is densely populated and would have difficulty absorbing new migrants. Also, far from having "abundant resources", it already experiences pressure on water sources. Large-scale agricultural expansion will require large amounts of water that are currently not available. Tso argues for the diversion of water from southern China, but this has the potential to create great ecological harm and international conflict, as discussed by A. Chen and C. Chen (Nature 429, 501; 2004).

Second, the arid Xinjiang region is more ecologically fragile than Tso suggests. Desertification has increased as a direct result of overgrazing and unsustainable farming practices. During the past 50 years the area of desert has increased by $4,210 \mathrm{~km}^{2}$, at an average rate of $84.2 \mathrm{~km}^{2}$ per year, while lakes have decreased from $9,700 \mathrm{~km}^{2}$ to $4,748 \mathrm{~km}^{2}$. Many famous lakes have actually disappeared.

The area's main river, the Tarim, has been steadily dwindling for 30 years as a result of dam building and irrigation upstream. This in turn has reduced the growth of vegetation, including ancient poplar groves, that had long formed a barrier between two deserts. It is now possible that the Taklimakan desert and the Kumtag desert will merge. Each year the frequency and intensity of dust storms increase, and the effects are felt as far away as Beijing, Tianjin, Korea and Japan. If more people move into Xinjiang, the problem of desertification will inevitably be exacerbated.

Finally, the large-scale migration proposed by Tso could have serious cultural implications. The Xinjiang region is inhabited by the Uighur people, the fifth largest ethnic minority in China. Immigration by ethnic Han people could alter traditional ways of life followed by the Uighur.

Development in Xinjiang requires an adequate understanding of its environment and people. Turning it into the "California of China" is not a viable option.

Wenwei Ren ${ }^{\star}$, Andrew A. Sacret $\dagger$

${ }^{*}$ Ministry of Education Key Laboratory for Biodiversity Science and Ecological Engineering, School of Life Sciences, Fudan University, Shanghai 200433, People's Republic of China $\dagger$ School of Urban and Regional Planning, Queen's University, Kingston, Ontario K7L3N6, Canada

\section{Bermuda welcomes careful prospectors}

Sir - Despite the claim in your News story "Bermuda gets tough over resource collecting" (Nature 429, 600; 2004), Bermuda's Ministry of the Environment has not shut down any research projects relating to biodiversity access, even on a temporary basis. New laws and regulations are under development to enhance bioprospecting, not to prevent or hinder such research activities.

Contrary to your News story, the Ministry of the Environment is not displeased with Diversa's research activities in Bermuda. The ministry greatly values the ongoing collaborations with the Bermuda Biological Station for Research (BBSR), and appreciates the station's responsibility in ensuring a proactive and consultative approach to issues of environmental access. Furthermore, Diversa, BBSR and the ministry look forward to exploring ways of expanding the bioprospecting benefits realized to date by the people and the government of Bermuda.

Jack A. Ward ${ }^{\star}$, Anthony Knap $\dagger$, Jay M. Short

${ }^{*}$ Ministry of the Environment, Government

Administration Building, 30 Parliament Street,

Hamilton HM 12, Bermuda

$\dagger$ Bermuda Biological Station for Research,
Ferry Reach, St George's GE 01, Bermuda $\$$ Diversa Corporation, 4955 Directors Place, San Diego, California 92121, USA

\section{Golden rule of economics yet to strike prospectors}

Sir-Your recent News Feature "Bioprospects less than golden" (Nature 429, 598-600; 2004) is the latest to document the disappointments of bioprospecting. It suggests that "new rules on ownership" might give bioprospecting a boost. Our experience leads us to doubt this conjecture. The reason commercial interests are not willing to pay much for biodiversity is that it is not worth much to them. This may seem paradoxical, given that new products can be worth billions of dollars, but our conclusion emerges from several basic principles of economics.

First, the spectacular earnings available from infrequent research successes must cover the far more common failures. Second, even in bioprospecting, costs are dominated by specialized labour and equipment rather than the chemical entities from which products are crafted. Finally, and most importantly, untested natural chemical entities are not scarce, and for that reason, they should not be expensive. A pharmaceutical researcher's willingness to pay for a natural product lead is determined by the probability that the lead will result in a useful new product multiplied by the probability that the same product would not be developed from any of the other leads available to the researcher. When there are large numbers of potential leads, successes must either be so unlikely as to make searching unattractive or so probable as to render competing leads redundant. Either way, researchers will not pay much for any particular untested product.

Your News Feature emphasizes that rules must be agreed for the allocation of genetic resources, and this is certainly important. Yet the biggest practical problem with bioprospecting may be unrealistic expectations. Our sense is that governments and advocates in developing countries have often been misled about the value of their biological wealth. Consequently, they hold out for spectacular gains that they are unlikely to achieve, and all too often forego the more modest but more readily achievable benefits such as those that your News Feature describes as arising from Phyllis Coley's programme in Panama.

David Simpson*, Roger Sedjo $\dagger$

${ }^{*}$ Department of Economics, University College London, Gower Street, London WC1E 6BT, UK $\dagger$ Resources for the Future, 1616 P Street NW, Washington DC 20036, USA 